\title{
Work-nonwork interference: Can ministers currently cope with increasing job demands against limited resources within South Africa?
}

\begin{tabular}{|c|c|}
\hline \multicolumn{2}{|c|}{$\begin{array}{l}\text { Authors: } \\
\text { Anso van der Westhuizen }{ }^{1} \\
\text { Eileen Koekemoer }^{1}\end{array}$} \\
\hline $\begin{array}{l}\text { Affiliations: } \\
{ }^{1} \text { School of Hun } \\
\text { Sciences, Econ } \\
\text { Management } \\
\text { Faculty, North } \\
\text { University, Pot } \\
\text { Campus, Soutł }\end{array}$ & $\begin{array}{l}\text { Ian Resource } \\
\text { omic and } \\
\text { sciences } \\
\text { West } \\
\text { chefstroom } \\
\text { Africa }\end{array}$ \\
\hline $\begin{array}{l}\text { Note: } \\
\text { For the variabl } \\
\text { this study: wor } \\
\text { spirituality int } \\
\text { combination '. } \\
\text { spirituality' is } \\
\text { in a functional } \\
\text { aim merely is } \\
\text { scientifically o } \\
\text { range of religic } \\
\text { that also exce } \\
\text { institutionalise } \\
\text { without gettin } \\
\text { in a theologica } \\
\text { discussion on } \\
\text { the relationshi } \\
\text { these two forn } \\
\text { expression. Na } \\
\text { extended pher } \\
\text { discussion falls } \\
\text { scope of this p } \\
\text { article. }\end{array}$ & $\begin{array}{l}\text { used in } \\
\text { k-religion/ } \\
\text { rference, the } \\
\text { religion/ } \\
\text { mployed } \\
\text { way. The } \\
\text { o focus } \\
\text { the wider } \\
\text { us experience } \\
\text { ds the } \\
\text { d structures } \\
\text { involved } \\
\text {-technical } \\
\text { he nature of } \\
\text { p between } \\
\text { is of religious } \\
\text { turally, such an } \\
\text { omenological } \\
\text { outside the } \\
\text { articular }\end{array}$ \\
\hline $\begin{array}{l}\text { This article is } p \\
\text { section Practic } \\
\text { of the Society } \\
\text { Theology in So }\end{array}$ & $\begin{array}{l}\text { ublished in the } \\
\text { al Theology } \\
\text { or Practical } \\
\text { uth Africa. }\end{array}$ \\
\hline $\begin{array}{l}\text { Corresponden } \\
\text { Eileen Koekem }\end{array}$ & $\begin{array}{l}\text { ce to: } \\
\text { oer }\end{array}$ \\
\hline $\begin{array}{l}\text { Email: } \\
\text { eileen.koekem } \\
\text { com }\end{array}$ & oer@gmail. \\
\hline $\begin{array}{l}\text { Postal address } \\
\text { PO Box X6001, } \\
\text { 114, Potchefst } \\
\text { South Africa }\end{array}$ & $\begin{array}{l}\text { Internal Mail } \\
\text { oom 2520, }\end{array}$ \\
\hline $\begin{array}{l}\text { Dates: } \\
\text { Received: } 01 \mathrm{~N} \\
\text { Accepted: } 03 \mathrm{~F} \\
\text { Published: } 29\end{array}$ & $\begin{array}{l}\text { ov. } 2013 \\
\text { eb. } 2014 \\
\text { May } 2015\end{array}$ \\
\hline $\begin{array}{l}\text { Read online: } \\
\text { 口iti }\end{array}$ & $\begin{array}{l}\text { Scan this QR } \\
\text { code with your } \\
\text { smart phone or } \\
\text { mobile device } \\
\text { to read online. }\end{array}$ \\
\hline
\end{tabular}

Authors:

Anso van der Westhuizen

Affiliations:

School of Human Resource Management Sciences

Faculty, North-West University, Potchefstroom

Campus, South Africa

Note: spirituality interference, the combination '... religion/ spirituality' is employed in a functional way. The scientifically on the wider range of religious experience that also exceeds the institutionalised structure discussion on the nature of the relationship between these two forms of religious expression. Naturally, such an discussion falls outside the scope of this particular

section Practical Theology of the Society for Practical

Correspondence to:

eileen.koekemoer@gmail.

PO Box X6001, Internal Mail

114 , Potchefstroom 2520

Africa

Accepted: 03 Feb. 2014

Published: 29 May 2015

Read online:
Ministers of religion have a unique occupation with designated job demands and incongruous resources at their disposal. Literature indicates that stressors within the work environment are significant predictors of work-nonwork interference. Ministers play a key role within society and provide support for individuals on multiple levels. However, limited studies are found in South Africa focussing on ministers' job characteristics related to work-nonwork interference, and how ministers cope. The main objective of this study was to investigate job demands and job resources as significant predictors of work-nonwork interference amongst ministers of religion, and to identify which coping strategies are most significant for ministers in dealing with work-nonwork interference. A cross-sectional survey design was used amongst ministers working in the three sister churches $(N=199)$. Various instruments were administered to measure job characteristics, work-nonwork interference and coping strategies empirically. Statistical analyses included descriptive statistics, product-moment correlations and multiple regression analyses. Results indicated that for ministers different job demands (i.e. cognitive demands and pace and amount of work) and job resources (i.e. financial support and job significance) significantly predicted work-parent, work-home and work-religion/spirituality interference. Results indicated turning to religion as the only significant coping strategy used by ministers to deal with work-parent interference and work-religion interference. Ministers of religion are continually exposed to increasing job demands and a lack of job resources, and therefore experience work-nonwork interference. Nevertheless, the ministers apparently cope by using the strategy best related to their profession, turning to religion/spirituality. Turning to religion/spirituality seems to be the most effective in dealing with work-nonwork interference.

\section{Introduction}

\section{Setting}

\section{Background to the study}

Religious leaders or ministers play an important role in the society by rendering services to individuals, families, churches and communities. From as early as 1957, literature began documenting the intense impact the ministry profession can have on ministers personally, as well as on their families (Bartlett 1957). Ministers are portrayed as support givers, who are exposed to demanding work situations, which can be characterised in terms of work-related and client-related stressors (Gibbs 2000). For many ministers work is not only a process or an occupation of caring; it rather is a special or higher calling to a way of life that they have to follow wholeheartedly (Grobbelaar 2007:86). However, the demands that ministers encounter in their work are in some instances regarded as more extreme than those experienced by managers in organisations (Kriel et al. 2005).

According to Nel (2002:151) the ministry, as a profession, is under severe stress. Darling, Hill and McWey (2004:262) stated that ministers are expected to be at the centre of enhancing the well-being of communities/individuals in society. Community members expect ministers to play an active role in the direct community. Such a situation adds extra stress onto ministers and their families. In an ever-changing world, ministers have to create a sense of stability for their congregation and the surrounding community. At the same time they have to cope with

How to cite this article: Van der Westhuizen, A. \& Koekemoer, E., 2015, 'Work-nonwork interference: Can ministers currently cope with increasing job demands against limited resources within South Africa?', HTS Teologiese Studies/Theological Studies 71(2), Art. \#2091, 11 pages. http://dx.doi.org/10.4102/hts.v71i2.2091

Copyright: @ 2015. The Authors. Licensee: AOSIS OpenJournals. This work is licensed under the Creative Commons Attribution License. 
global changes, economic difficulty, social changes, stressors and the impact these factors have on them and their ministry (Buys 2008:25).

\section{Trends from the literature}

In South Africa, ministers are exposed to a variety of possible job stressors. These include personal and professional criticism, high expectations posed on religious leaders and their families by congregations, financial stressors and boundary ambiguity (Swart 2002:15). In addition to this tendency, Hill, Darling and Raimondi (2003:161) explained that most of the stress that ministers experience could be connected directly or indirectly to these boundary-related factors. Most of the helping professions have a built-in defence mechanism that keeps people's work efforts within the recognised boundaries, as is the case with normal working employees (Hill et al. 2003:150). However, Grosch and Olsen (2000) found that religious leaders lack such a defence mechanism. Therefore ministers may find it hard to learn how to implement those restrictions, given the high job demands and expectations of having to 'diversify' themselves to serve individuals. Ministers have to cope with demands that arise from having to fulfil a range of multiple ministerial roles (Jansen van Vuuren 2005:9). In this sense, ministers constantly are trying to keep up expectations of having to deal with occupational demands and having to cope with other people's problems (Grosch \& Olsen 2000). This state of affairs alone will cause stress levels to intensify in the course of time (Grosch \& Olsen 2000).

Mauno, Kinnunen and Ruokolainen (2006:212) explain that job demands can be classified as a strong predictor of strain, whereas job resources are associated more vigorously with different motivational outcomes. Darling et al. (2004) suggest that the important difference in the ministers' occupation might be in respect of personal resources that are available. Research found that ministers scored high in occupational and vocational stress, but low in overall personal resources (Darling et al. 2004:262). Theoretically, the relationship can be explained as high levels of demands at work. This requires a focus on personal resources in this area, hence leaving fewer resources to challenge demands in other spheres, for example, that of the family (Hall et al. 2010:239). Individuals who have to deal with the absence of resources in their work and personal spheres are more prone to experience a descending spiral of extra losses in other domains (Demerouti, Bakker \& Bulters 2004).

The lack of resources against the increasing demands has an immense impact on the ministers as well as on their families and spouses (Darling et al. 2004). This makes it difficult to conserve the different roles they need to fulfil. Ministers have access to different resources that are based either individually (i.e. personality factors, family supportive climate), or on an organisational structure (i.e. autonomy, job control). These resources thus can play a vital buffering role in lessening or restraining the negative effects of job demands (Mauno et al. 2006:225). Stress intensifies and problems increase within the ministers' family sphere when they are not present to tend to issues in their own household (Darling et al. 2004:272). Hill et al. (2003) state that ministers should be cautious in protecting the time they have with their families.

Within the frantic pace of modern life, the matter of worknonwork interference/interaction has received a lot of attention from researchers within the field of human resource sciences during the past years (Allen, Herst, Bruck \& Sutton 2000; Bulger, Matthews \& Hoffman 2007; Geurts \& Demerouti 2003; Koekemoer, Mostert \& Rothmann 2010). Harsh economic realities often keep employees busy and may even cause job overload. This means that many employees experience increasing difficulties in balancing the demands of work and family life, with even less time for other social activities. This is especially found in caring professions such as nursing, psychology, ministry and social work (Bakker et al. 2011; Innstrand, Langballe \& Falkum 2010; Kalliath \& Kalliath 2013; Yildirim \& Aycan 2008).

\section{Key focus of the study}

The ongoing changes in modern life play a predominantly important role in the experience of work-nonwork interference (Mauno et al. 2006:211). Ministers' work and the stress it delivers do not only influence the minister as a person, but also have immense consequences for his or her family as a unit (Hill et al. 2003). Ministers and their families spend long hours supporting others and acting in stressful situations, which in time influence their rapport with one another (Buys 2008:2). Research has demonstrated that interfering demands (i.e. invasion of privacy) have potentially harmful disadvantages to the outlook and wellbeing of ministers as well as for their families (Han \& Lee 2004:477). Unfortunately the spouses of the ministers share in the demands and also in the accompanying exhaustion (Darling et al. 2004). However, as spouses they miss out on the positive influence of empathy, consideration and work satisfaction that the ministers experience (Darling et al. 2004). Religious leaders and their spouses experience a greater amount of loneliness and diminished marital adjustment in comparison with males and females who are not part of the ministry profession (Darling et al. 2004). In addition, according to Hang-yue, Foley and Loi (2005:2134) ministers who are married and have children, are more likely to experience work-nonwork interference.

People continually encounter the current reality of working life and the stress-producing environment of work that impacts on their daily existence (and vice versa) (Mauno et al. 2006). Therefore it is compulsory to reassess what resources might help - either directly to improve worknonwork interference, or indirectly, to decrease (i.e., restrain, safeguard against) its negative outcomes (Mauno et al. 2006). If ministers do experience work-nonwork interference, they would need to know how to handle the various forms of stress that impact on their lives (Doolittle 2010; Hill et al. 2003; Innstrand et al. 2010; Pargament et al. 2002). One of the approaches ministers could use to decrease such negative 
outcomes is by employing effective coping mechanisms. Francis et al. (2000:278) contended that in many aspects, ministry as a profession needs continuous ministry-related education to develop effective coping strategies for diverse stress-related situations.

Only a few studies have been done on how ministers cope within their stressful environments (Hill et al. 2003; Jansen van Vuuren 2005). Hill et al. (2003:160) describe the use of planning as a coping strategy (e.g. prioritising work) as an effective way of coping for ministers. Jansen van Vuuren (2005:60) found that problem-focused coping had a significant impact on ministers' emotional demands. In contrast to this, problem-focused coping had a relatively small impact on the general health of ministers when compared to work-related stressors.

According to Hill et al. (2003:160), by prioritising work, ministers can create time to spend with people who can provide them with the necessary support. When a minister connects with members within a congregation or a faith community, it enables a supporting system, as well as enhanced relations to receive support from others. Support for ministers who are dealing with issues such as loss, conflict between friends and congregational and familyrelated matters, would be helpful to reduce feelings of stress (Meisenhelder \& Marcum 2004:553). Carver, Scheier and Weintraub (1989) described this type of social networking as the seeking-emotional-support. Spending time with family and friends, as well as continuous prayer, were the coping strategies for ministers that related the most strongly to a decrease in stress responses in the study amongst 9/11 survivors (Meisenhelder \& Marcum 2004:553).

Another coping strategy Koenig, McCullough and Larson (2001) found to be associated with reduced stress and other forms of improved mental health, is the notion of turning to religion. According to Meisenhelder and Marcum (2004:548), a positive form of religious coping represents both a turning to God and a positive faith in God. There is growing evidence that individuals, who seek religion in their lives through regular religious practices, whether in congregation or private, are healthier and live longer than those adults who participate less in religion (Koenig et al. 2001).

\section{Potential added value of the study}

In addition to the coping strategies mentioned above, there still are exceedingly different coping strategies, as described by Carver et al. (1989). It is not clear from the literature which types of coping strategies, or perhaps which combination of coping strategies, are most beneficial for individuals who experienced a traumatic event or situation (Haden et al. 2007:1189). Numerous studies have been undertaken in South Africa on job demands and job resources, as well as the work-nonwork interference, work-family conflict or workhome interference (Mostert, Peeters \& Rost 2010; Rantanen et al. 2011; Koekemoer 2010; Koekemoer \& Mostert 2006). However, only a few studies were found which included coping strategies in their research (Mostert \& Oosthuizen 2006). Coping can be seen as a basic component that enables a person to develop and adapt in different situations.

From the above, it is clear that there is a need to investigate ministers' experience of their work environment and possible work-nonwork interference. Ministers experience various situations, which lead to different challenges in their work. It is important to investigate the possibility that ministers in South Africa may be experiencing a lack of resources as against too many demands.

\section{Objectives}

Given this background, the main objective of this study was to investigate job demands and job resources as significant predictors of work-nonwork interference amongst ministers of religion, and also to investigate which coping strategies are the most significant in dealing with work-nonwork interference.

\section{Literature review}

\section{Theoretical framework - Job demands and Job resources model}

The Job Demand-Resources model (JDR-model) (Demerouti et al. 2001; Schaufeli \& Bakker 2004) has been applied to different studies (Bakker \& Demerouti 2006; Buys 2008; Buys \& Rothmann 2009; Demerouti et al. 2001; Schaufeli \& Bakker 2004; Van Emmerik, Bakker \& Euwema 2009). However, only a few studies included this model along with worknonwork interference (Koekemoer \& Mostert 2006; Mostert et al. 2010; Oosthuizen, Koekemoer \& Mostert 2011). The JDR-model (Bakker \& Demerouti 2006; Demerouti et al. 2001) specifies how well-being and motivation may be produced as a consequence of working conditions. This model suggests that, even though each occupation presents its own unique job characteristics, these characteristics can be classified into job demands and job resources (Bakker, Demerouti \& Verbeke 2004). According to Bakker and Demerouti (2006), the JDRmodel suggests two independent processes explaining the well-being of an individual (Bakker \& Demerouti 2006).

The first process included aspects such as strain, health impairment, chronic demands and stressors of an occupation or an individual experience which over time may lead to health problems and/or breakdown. The second process concerns the job resources which may help an individual to cope with these demands (Bakker \& Demerouti 2006).

\section{Work-nonwork interference}

Over the past two decades researchers have studied the field of work and family conflict (including the different denominations thereof), as well as the impact on the work and family domains of peoples' personal lives (Doumas, Margolin \& John 2008; Glaser, Evandrou \& Tomassini 2006; Lee \& Phillips 2006; Premeaux, Adkins \& Mossholder 2007). In the literature the most widely used definition for the interference between work and family life is that of 
Greenhaus and Beutell (1985). The definition states that work-family conflict presents a form of inter-role conflict where role pressures from the work and family domains are mutually incompatible in some respect and where conflict can occur in either direction (i.e. the work-family or familywork conflict). Consequently, researchers have expanded the concept of conflict by outlining the direction it follows, the roles that are affected, and the nature of the conflict (see Koekemoer, Mostert \& Rothmann 2010; overviews of Allen et al. 2000; Byron 2005; Mesmer-Magnus \& Viswesvarum 2005).

However, very few instruments have been developed that were able to measure the specific interference between work and the nonwork domains (Koekemoer \& Mostert 2010). Koekemoer et al. (2010) developed and tested such an instrument within the South African context. These authors have conceptualised work-nonwork interference:

\begin{abstract}
as a process in which the involvement of an individual in one domain (or social role) interferes with the functioning or involvement in another domain (role). In this sense, the interference affects the way in which the worker's self-identity is influenced by external stimuli to such an extent that it leads to an inadequate performance of behaviour confirming one or more highly-salient identities/roles. (Koekemoer et al. 2010:2)
\end{abstract}

Koekemoer et al. (2010) identified four dimensions aiding the evaluation of work-nonwork interference and nonwork-work interference, namely: work-parent interference, work-spouse interference, work-domestic interference and work-religion/ spirituality interference. Although this instrument was developed to cater for four dimensions during the construct validity in the present study, it was found to be more valid with only three dimensions (work-parent interference, work-home interference and work-religion/spirituality interference).

\section{Coping strategies}

Carver et al. (1989) divided coping strategies into two subdivisions. Firstly, problem-focused coping is designed for problem-solving or doing something to adjust the source of the stress. Secondly, emotion-focused coping is aimed at reducing or managing the emotional distress that is associated with a certain situation (Carver et al. 1989). Pienaar and Rothmann (2003) re-evaluated the COPE questionnaire and developed it for the South African context. Their findings suggested four coping strategies (i.e. approach coping, avoidance, seekingemotional-support and turning to religion) to be measured with the COPE (Pienaar \& Rothmann 2003).

\section{Research method and design Research approach}

A cross-sectional survey design or approach was utilised in this study. This method is designed to utilise a sample where data are drawn from a population at one point in time (Salkind 2009) and enables researchers to collect measurable data and to detect patterns or a relationship between two or more variables (Bryman \& Bell 2007).

\section{Research participants}

A random sample $(N=199)$ was taken from ministers of the three Reformed sister churches in South Africa (with a response rate of $35 \%$ ). Due to the conceptualisation and measurement of the dimensions of work-nonwork interference, only ministers who were married (or perhaps divorced or widowed), and who had children, were included in this study.

Participants were mainly white $(97.50 \%)$, Afrikaans-speaking (96.50\%) males (87.4\%). Although all of the participants had children and the majority of them were married (93.50\%), some were widowed $(2.50 \%)$ or divorced $(4 \%)$. Most of the participants had two $(36.20 \%)$ or three children $(35.20 \%)$, with these children still living at home (54.30\%). The majority of ministers were respectively from the Dutch Reformed Church in South Africa (Nederduitse Gereformeerde Kerk in Suid-Afrika) (46.70\%) and the Dutch Reformed Church in Africa (Nederduitsch Hervormde Kerk in Afrika) (39.20\%). Most of the participants acted as the only minister in service of their congregation $(62.80 \%)$, whereas only $20.60 \%$ of the participants indicated that their congregations had two ministers in service. Less than half of the participants managed a congregation with a size of more than 500 members $(46.20 \%)$.

\section{Measuring instruments}

The following measurement instruments were utilised in the empirical study.

Job demands and job resources: Items were used from the cognitive demands construct developed by Peeters et al. (2005) (4 items, e.g., 'our work requires you to concentrate continuously.' The items were evaluated on a four-point Likert scale ranging from 0 ('never') to 3 ('always'). In Koekemoer and Mostert (2010), the cognitive demand construct was found valid and reliable within the South African context $(\alpha=0.71)$.

The Job Demands-Resources Questionnaire (JD-RQ) of Buys and Rothmann (2009) was used to measure additional job demands and resources. They initially developed the questionnaire to measure the experienced job demands and job resources of specifically ministers of religion. In this study the construct validity was proven for the following demands and resources: emotional demands (5 items, e.g., 'Does your work put you in emotionally upsetting situations?'); pace and amount of work (6 items, e.g., 'Do you have to work under time pressure?'); congregational support (6 items, e.g. 'Do your congregation and church council let you know how well you are performing your job?'); financial support (4 items, e.g. 'Do you feel that you get paid enough for your work?'); lack of autonomy (5 items, e.g. 'Do you feel that your ideas or suggestions about your congregation are not taken into account?'); social support (6 items, e.g. 'Do you receive support from your friends when things get difficult at work?'); job significance (8 items, e.g. 'Do you feel that 
you have enough variety in your work right now?') and job accomplishment (5 items, e.g. 'Do you feel that you are moving forward in your job?'). Items were evaluated on a five-point Likert scale, ranging from 1 ('not at all') to 5 ('a great deal').

In accordance with Buys and Rothmann (2009), all the dimensions were found valid and reliable (pace and amount of work, $\alpha=0.84$; emotional demands, $\alpha=0.79$; growth opportunity, $\alpha=0.84$; instrumental support, $\alpha=0.86$; job significance ( $\alpha=0.66)$; congregational support, $\alpha=0.82$; autonomy, $\alpha=0.70$; and social support, $\alpha=0.84$ ), when compared to guidelines for alpha coefficients to be larger than 0.70 (Nunnally \& Bernstein 1994) .

Work-nonwork interference: Items were used from the Work-Nonwork Interference Instrument (W-NWI) from Koekemoer et al. (2010). Although this instrument measures interference in both directions (i.e. work to nonwork and nonwork to work), in the present study the interference was measured only in one direction (i.e. from the work domain to the nonwork domains or roles). Based on the construct validity found in the present study, the spouse and domestic interference dimensions were combined to create a workhome interference dimension factor. The dimensions of work-nonwork interference reported in this study were thus work-parent interference (5 items, e.g., 'How often does it happen that your work keeps you from your child(ren) more than you like?'); work-home interference (11 items, e.g., 'How often does it happen that your marriage/relationship with your spouse/partner suffers because of your work?'); and lastly, work-religion/spirituality interference (6 items, e.g., 'How often does it happen that your work interferes with your religion/spirituality?'). Items were evaluated on a four-point Likert scale ranging from 0 ('never') to 3 ('always'). For Koekemoer et al. (2010), all results indicated that the scales were valid and reliable (work-parent interference, $\alpha=0.88$; work-spouse interference, $\alpha=0.88$; work-domestic interference, $\alpha=0.91$ and work-religion/ spiritual interference, $\alpha=0.86$ ), when compared to the guidelines of Nunnally and Bernstein (1994).

Coping strategies: Items from the Coping questionnaire (COPE) (Carver et al. 1989) were employed to determine the participants' use of various coping strategies. The COPE is a multidimensional coping questionnaire comprising 53 items, which indicate the various ways that people cope in different circumstances (Carver et al. 1989). The initial questionnaire measures 13 different coping strategies, which are divided between problem-focused and emotion-focused coping strategies.

This instrument was re-evaluated for the South African context by Pienaar and Rothmann (2003) and found reliable. Their findings suggested that the COPE could be employed to measure four coping strategies (Pienaar \& Rothmann 2003). These coping strategies include: approach coping, avoidance, seeking-emotional-support and turning to religion (Pienaar
\& Rothmann 2003). In Pienaar and Rothmann (2003) these scales where all found reliable (Nunnally \& Bernstein 1994); approach coping, $\alpha=0.92$; avoidance, $\alpha=0.86$; seekingemotional-support, $\alpha=0.80$ and turning to religion, $\alpha=0.83$.

In the present study construct validity was proven for six coping strategies, which is more closely related to the original findings of Carver et al. (1989). These include: turning to religion (3 items, 'I put my trust in God'), seeking-emotionalsupport ( 5 items, 'I try to get emotional support from friends and relatives'), active coping (4 items, 'I take additional action to try to get rid of the problem'), acceptance coping (7 items, 'I accept that this has happened and that it can't be changed'), planning (5 items, 'I make sure not to make matters worse by acting too soon') and avoidance (7 items, 'I pretend that it hasn't really happened'). These strategies were measured on a five-point Likert scale ranging from 1 ('not at all') to 5 ('a great deal').

\section{Research procedure and ethical considerations}

The ministers were contacted by means of two methods. The first method was approach through email, and the second method entailed a more personal face to face approach. The initial goal of approaching the ministers was to enquire whether they wanted to participate in the study. In following the first method, a list of email addresses from ministers was obtained from the interlinked website of the three Reformed sister churches. An initial email containing the information of the study was sent to all ministers enquiring whether they wanted to participate in the study. The ministers who responded positively received the questionnaire via email.

The distribution package contained a letter explaining the goal and importance of the study and provided the contact information of the researcher in case of queries. The confidentiality and anonymity of participation were clearly confirmed in the letter. The letter also explained that, should the recipient request a hard copy of the questionnaire, one could be sent to him or her. This package contained an anonymous stamped envelope which they could use to send the information directly to the researcher. If the ministers responded through email the documentation was handled by the researcher only, so as to assure that the respondents' data were kept anonymous.

For the second method, hard copies were also handed out at different congregations along with an anonymous envelope and stamp, again enabling the recipient to post the completed form directly to the researcher.

\section{Statistical analysis}

At the outset of the statistical analysis, construct validity of all the instruments were proven by using confirmatory factor analyses (CFA) in the Statistical Package for the Social Sciences (SPSS) programme. In addition, Cronbach's alpha coefficients were used to assess the reliability of the instruments (Clark \& Watson 1995). The descriptive statistics using the SPSS 
program were employed to clarify the overall and coherent picture of a large amount of data, which included mean and standard deviation (Struwig \& Stead 2001).

The product-moment correlations were used to explain the relationships between the variables (Struwig \& Stead 2001). For the statistical analysis, it was decided to set the value at a $99 \%$ confidence interval level of $(p<0.01)$. The cut-off points for the practical significance of the correlations were 0.30 (medium effect) and 0.50 (large effect) respectively (Cohen 1988; Field 2013). The Pearson product-moment correlations were used to establish the linear relationship between variables, whilst the Spearman method was used when the data was not normally distributed.

Multiple regression analyses were also carried out by means of the SPSS program. According to Struwig and Stead (2001), this technique is used to determine the extent to which the independent variables predict a dependent variable. Such a technique was employed to determine the percentage variance in the dependent variables (the dimensions of the work-nonwork interference), which were predicted by the independent variables (e.g. job demands, job resources and coping strategies). According to Baron and Kenny (1986), it is more preferable to assess the impact of the independent variable on the dependent variable not by correlation coefficients, but by regression coefficients.

During the first step of the regression analyses job demands were entered as predictors; during the second step job resources were added, and in the final step coping strategies were added as predictors of the dimensions of worknonwork interference.

\section{Results}

Descriptive statistics and product-moment correlations Descriptive statistics, Cronbach's alpha coefficients and correlation coefficients are reported in Table 1.

Table 1 indicates acceptable reliability coefficients for all of the constructs, except for lack of autonomy $(\alpha=0.69)$, which are just below the cut-off of 0.70 (Nunnally \& Bernstein 1994). Furthermore, Table 1 provides the correlation coefficients.

Work-parent interference was positively statistically significantly related to all three demands measured in this study and showed negative statistical significant relationships with financial support, social support and turning to religion.

TABLE 1: Descriptive statistics and product-moment correlations for job demands, job resources, coping strategies and dimensions of work-nonwork interference.

\begin{tabular}{|c|c|c|c|c|c|c|c|c|c|c|c|c|c|c|c|c|c|c|}
\hline Item & 1 & 2 & 3 & 4 & 5 & 6 & 7 & 8 & 9 & 10 & 11 & 12 & 13 & 14 & 15 & 16 & 17 & 18 \\
\hline $\begin{array}{l}\text { 1. Cognitive } \\
\text { demands }\end{array}$ & 1 & - & - & - & - & - & - & - & - & - & - & - & - & - & - & - & - & - \\
\hline $\begin{array}{l}\text { 2. Emotional } \\
\text { demands }\end{array}$ & $0.30 \dagger *$ & 1 & - & - & - & - & - & - & - & - & - & - & - & - & - & - & - & - \\
\hline $\begin{array}{l}\text { 3. Pace and } \\
\text { amount of work }\end{array}$ & $0.44 \dagger^{*}$ & $0.50 \dagger * *$ & 1 & - & - & - & - & - & - & - & - & - & - & - & - & - & - & - \\
\hline $\begin{array}{l}\text { 4. Congregational } \\
\text { support }\end{array}$ & 0.15 & $-0.28 \dagger$ & 0.09 & 1 & - & - & - & - & - & - & - & - & - & - & - & - & - & - \\
\hline $\begin{array}{l}\text { 5. Financial } \\
\text { support }\end{array}$ & -0.03 & $-0.21 \dagger$ & -0.02 & $0.32 \dagger^{*}$ & 1 & - & - & - & - & - & - & - & - & - & - & - & - & - \\
\hline $\begin{array}{l}\text { 6. Lack of } \\
\text { autonomy }\end{array}$ & 0.17 & $0.44 \dagger^{*}$ & 0.15 & $-0.51 \dagger * *$ & $-0.31 \dagger^{*}$ & 1 & - & - & - & - & - & - & - & - & - & - & - & - \\
\hline 7. Social support & 0.01 & $-0.29 \dagger$ & -0.06 & $0.60 \dagger * *$ & $0.29 \dagger$ & $-0.38+*$ & 1 & - & - & - & - & - & - & - & - & - & - & - \\
\hline 8. Job significance & $0.35 \dagger^{*}$ & -0.00 & $0.35 \dagger *$ & $0.56+* *$ & 0.22 & $-0.36 \dagger^{*}$ & $0.38 \dagger^{*}$ & 1 & - & - & - & - & - & - & - & - & - & - \\
\hline $\begin{array}{l}\text { 9. Job } \\
\text { accomplishment }\end{array}$ & 0.18 & $-0.30 \dagger^{*}$ & 0.08 & $0.61 \dagger * *$ & $0.40 \dagger^{*}$ & $-0.41 \dagger^{*}$ & $0.55 \uparrow * *$ & $0.62 \dagger * *$ & 1 & - & - & - & - & - & - & - & - & - \\
\hline $\begin{array}{l}\text { 10. Turning to } \\
\text { religion }\end{array}$ & 0.02 & -0.08 & 0.18 & $0.32 \dagger^{*}$ & 0.09 & $-0.27 \dagger$ & $0.21 \dagger$ & $0.44 \dagger^{*}$ & 0.20 & 1 & - & - & - & - & - & - & - & - \\
\hline $\begin{array}{l}\text { 11. Seeking- } \\
\text { emotional-support }\end{array}$ & -0.05 & -0.06 & -0.13 & $0.26 \dagger$ & 0.16 & -0.13 & $0.39 \dagger *$ & 0.15 & 0.19 & 0.16 & 1 & - & - & - & - & - & - & - \\
\hline 12. Active coping & 0.11 & 0.05 & 0.09 & $0.28 \dagger$ & -0.01 & -0.17 & $0.23 \dagger$ & $0.21 \dagger$ & 0.14 & $0.36+*$ & $0.31 \uparrow^{*}$ & 1 & - & - & - & - & - & - \\
\hline $\begin{array}{l}\text { 13. Acceptance } \\
\text { coping }\end{array}$ & -0.07 & -0.02 & 0.03 & 0.06 & 0.11 & -0.14 & 0.11 & 0.14 & 0.05 & $0.36+*$ & $0.24 \dagger$ & $0.36+*$ & 1 & - & - & - & - & - \\
\hline $\begin{array}{l}\text { 14. Planning } \\
\text { coping }\end{array}$ & 0.14 & 0.07 & 0.20 & $0.22 \dagger$ & 0.05 & -0.19 & 0.06 & $0.28 \dagger$ & 0.02 & $0.47+*$ & 0.18 & $0.34 \dagger *$ & $0.26 \dagger$ & 1 & - & - & - & - \\
\hline $\begin{array}{l}\text { 15. Avoidance } \\
\text { coping }\end{array}$ & -0.00 & 0.16 & -0.17 & $-0.29 \dagger$ & -0.08 & $0.31+*$ & -0.10 & $-0.32 \dagger^{*}$ & -0.09 & $-0.40 \dagger *$ & 0.08 & -0.11 & -0.01 & $-0.36 \dagger^{*} *$ & 1 & - & - & - \\
\hline $\begin{array}{l}\text { 16. Work-parent } \\
\text { interference }\end{array}$ & $0.24 \dagger$ & $0.28 \dagger$ & $0.31 \% *$ & -0.16 & $-0.22 \dagger$ & $0.26 \dagger$ & $-0.24 \dagger$ & -0.12 & -0.17 & $-0.22 \dagger$ & -0.05 & -0.08 & 0.00 & -0.10 & 0.13 & 1 & - & - \\
\hline $\begin{array}{l}\text { 17. Work-home } \\
\text { interference }\end{array}$ & 0.20 & $0.34 \dagger^{*}$ & $0.46+*$ & $-0.22 \dagger$ & $-0.25 \dagger$ & $0.29 \dagger$ & $-0.27 \dagger$ & -0.12 & $-0.24 \dagger$ & -0.11 & -0.09 & -0.01 & -0.07 & -0.05 & 0.04 & $0.71 \uparrow * *$ & 1 & \\
\hline $\begin{array}{l}\text { 18. Work-religion } \\
\text { interference }\end{array}$ & 0.19 & $0.37+*$ & $0.29 \dagger$ & $-0.33 \dagger^{*}$ & $-0.26 \dagger$ & $0.40 \dagger^{*}$ & $-0.33 \dagger *$ & $-0.28 \dagger$ & $-0.29 \dagger$ & $-0.35 \dagger^{*}$ & -0.11 & -0.19 & -0.20 & -0.16 & $0.21 \dagger$ & $0.63 \dagger * *$ & $0.69 \div * *$ & 1 \\
\hline M & 2.12 & 3.31 & 3.53 & 3.32 & 2.63 & 2.34 & 3.27 & 4.04 & 3.22 & 3.34 & 2.47 & 3.06 & 2.89 & 3.17 & 1.88 & 1.13 & 1.15 & 1.02 \\
\hline SD & 0.58 & 0.82 & 0.71 & 0.78 & 0.94 & 0.72 & 0.95 & 0.61 & 0.81 & 0.77 & 0.71 & 0.64 & 0.59 & 0.65 & 0.56 & 0.63 & 0.53 & 0.59 \\
\hline Reliabilities $(\alpha)$ & 0.82 & 0.74 & 0.77 & 0.81 & 0.77 & 0.69 & 0.85 & 0.82 & 0.80 & 0.83 & 0.81 & 0.73 & 0.78 & 0.80 & 0.74 & 0.87 & 0.92 & 0.86 \\
\hline
\end{tabular}

The correlations marked in bold typeface are most significant to the specific objectives.

$\dagger$, Statistically significant $(p<0.01)$

$\mathrm{M}$, mean; SD, standard deviation.

*, Correlation is practically significant $r>0.30$ (medium effect); **, Correlation is practically significant $r>0.50$ (large effect). 
Work-home interference was positively practically and statistically significantly related only to emotional demands and pace and amount of work (medium effect), and showed negative and statistical significant relationships with congregation support, financial support, social support and job accomplishment.

Work-religion/spirituality interference was positively practically and statistically significantly related to emotional demands and only statistically related to pace and amount of work. Work-religion/spirituality was practically statistically significantly related to congregational support, social support and turning to religion with medium effects. Only negative statistical relationships were found with financial support, job significance and job accomplishment. A positively statistically significant relationship was found with avoidance coping. All three dimensions of work-nonwork interference showed positive and statistical significant relationships with lack of autonomy.

Following the descriptive statistics and correlations, three multiple regression analyses were done in order to determine the significant predictors of the various dimensions of worknonwork interference.

\section{Multiple regression analyses}

Table 2 summarises the regression analyses with the various job demands, job resources and coping strategies as predictors of the three work-nonwork interference dimensions.

\section{Work-parent interference as dependent variable}

Table 2 indicates that, for work-parent interference, entry of the job demands in the first step produced a statistical significant model accounting for $13 \%$ of the variance. Upon entry of the second step, job resources, the results were significant and accounted for an additional $8 \%$ of the variance. During the third and final step, when coping strategies were entered, an additional $6 \%$ of the variance was explained. This final model was significant and explained $27 \%$ of variance during which cognitive demands, pace and amount of work, financial support and turning to religion were identified as significant predictors for work-parent interference.

\section{Work-home interference as dependent variable}

Regarding work-home interference, Table 2 indicates that job demands in the first step produced a statistical significant accounting for $23 \%$ of the variance. Job resources in the second step significantly accounts for an additional 12\% of the variance. In the third and final step, coping strategies accounted for an additional $1 \%$ of the variance. The final model was significant and explained $36 \%$ of the variance, indicating pace and amount of work and financial support as predictors of work-home interference.

\section{Work-religion/spirituality interference as dependent variable}

For work-religion/spirituality interference job demands in the first step produced a statistical significant model accounting for $16 \%$ of the variance. Job resources which were entered during the second step produced for a statistically significant model which explained an additional $18 \%$ of the variance. In the third and final step, coping strategies were entered, which accounted for an additional $6 \%$ of the variance. The final model was significant and accounted for $40 \%$ of the variance indicating pace and amount of work, job significance and turning to religion as significant predictors of work-religion/spirituality interference.

\section{Discussion \\ Outline of the results}

Ministers have one of the most thought-provoking and challenging occupations (Du Plessis 2009:328). Only a few studies have been completed amongst ministers in South Africa, measuring their work-related well-being (Buys 2008;

TABLE 2: Multiple regression analyses with dimensions of work-nonwork interference as dependent variables.

\begin{tabular}{|c|c|c|c|c|c|c|c|c|c|}
\hline \multirow{2}{*}{$\begin{array}{l}\text { Dependent variables (Independent } \\
\text { variables included) }\end{array}$} & \multicolumn{3}{|c|}{ Work-parent interference } & \multicolumn{3}{|c|}{ Work-home interference } & \multicolumn{3}{|c|}{ Work-religion interference } \\
\hline & Step 1 & Step 2 & Step 3 & Step 1 & Step 2 & Step 3 & Step 1 & Step 2 & Step 3 \\
\hline Cognitive demands & 0.11 & $0.16^{*}$ & $0.16 *$ & -0.03 & 0.04 & 0.04 & 0.05 & 0.13 & 0.10 \\
\hline Emotional demands & $0.15^{*}$ & 0.03 & 0.00 & $0.15^{*}$ & -0.02 & -0.04 & $0.30 * *$ & 0.11 & 0.08 \\
\hline Pace and amount of work & $0.18^{*}$ & $0.28 * *$ & $0.34 * *$ & $0.40 * *$ & $0.52 * *$ & $0.55^{* *}$ & 0.12 & $0.27 * *$ & $0.33 * *$ \\
\hline Congregational support & - & 0.02 & 0.07 & - & -0.03 & -0.04 & - & -0.08 & -0.04 \\
\hline Financial support & - & -0.13 & $-0.16 *$ & - & $-0.14^{*}$ & $-0.13 *$ & - & -0.11 & -0.12 \\
\hline Lack of autonomy & - & 0.04 & 0.00 & - & 0.05 & 0.02 & - & 0.10 & 0.05 \\
\hline Social support & - & -0.10 & -0.15 & - & -0.07 & -0.11 & - & -0.09 & -0.11 \\
\hline Job significance & - & $-0.21 *$ & -0.13 & - & $-0.20 *$ & -0.15 & - & $-0.33 * *$ & $-0.22 *$ \\
\hline Job accomplishment & - & 0.03 & -0.03 & - & -0.04 & -0.07 & - & 0.09 & 0.02 \\
\hline Turning to religion & - & - & $-0.19 *$ & - & - & -0.06 & - & - & $-0.19 *$ \\
\hline Seeking-emotional-support & - & - & 0.11 & - & - & 0.11 & - & - & 0.12 \\
\hline Active coping & - & - & -0.06 & - & - & 0.05 & - & - & -0.08 \\
\hline Acceptance coping & - & - & 0.14 & - & - & -0.02 & - & - & -0.06 \\
\hline Planning coping & - & - & -0.09 & - & - & -0.10 & - & - & -0.03 \\
\hline Avoidance coping & - & - & 0.02 & - & - & -0.02 & - & - & 0.03 \\
\hline Model $R 2$ & 0.13 & 0.21 & 0.27 & 0.23 & 0.35 & 0.36 & 0.16 & 0.34 & 0.40 \\
\hline Model $\triangle R 2$ & 0.13 & 0.08 & 0.06 & 0.23 & 0.12 & 0.01 & 0.16 & 0.18 & 0.06 \\
\hline
\end{tabular}

Instances where missing values are found in the table, specific variables were not included in the various steps.

$*$, statistically significant $(p<0.05) ; * *$, statistically significant $(p<0.01)$ 
Buys \& Rothmann 2009; Du Plessis 2009, Grobbelaar 2007; Jansen van Vuuren 2005). The unique job characteristics, together with the fact that few studies were undertaken on the topic, led to the main objective of the present study. This objective was to investigate job demands and job resources as significant predictors of work-nonwork interference for ministers of religion and also to investigate the relevant coping strategies which are significant in dealing with such interference.

Prior to investigating the significant predictors of worknonwork interference, the relationships between job demands, job resources and work-nonwork interference were investigated empirically. The results showed that cognitive demands (the psychological constraint that ministers undergo) had a positive relationship with the dimension of work-parent interference. This could indicate that, when ministers spend time with their children (or fulfil their parental role), they are also cognitively (mentally) occupied with their work. This is in line with previous findings of $\mathrm{Nel}$ (2011) as well as Oosthuizen et al. (2011).

The variables emotional demands and pace and amount of work were also significantly positively related to all three dimensions of work-nonwork interference. This therefore indicates that the more emotional demands ministers have to handle, the more interference they experience in the other nonwork roles in their lives. This could indicate that the more emotional stressors the ministers experience, the higher the risk that these stressors could interfere with the relationship they have with their children, home and religious activities. This may also suggest that the more work ministers have and the more pressure is put on them to complete the tasks within a specific time-frame (i.e. pace and amount of work), the less time they spend with their children, at home or are involved in religious activities. Both Koekemoer and Mostert (2010) and Oosthuizen et al. (2011) found statistical, practical and significant correlations between the emotional demands and pace and amount of work, as well as the various dimensions of work-nonwork interference, even though they did not conduct their studies amongst ministers.

In terms of the resources investigated in this study, the variable lack of autonomy was positively related to all three dimensions of work-nonwork interference. This suggests that the more autonomy ministers experience, the less interference is experienced on all dimensions of work-nonwork interference. Nel (2011) previously found that autonomy had a positive correlation with the different dimensions of work-nonwork interference: work-parent interference, work-spouse interference and work-home interference. In the present study, financial support and social support each had negative correlations with all the dimension of work-nonwork interference. This indicates that the more financial support and social support ministers receive, the less their work environment interferes with their children, home and religion/spiritual activities. This is in line with the findings of Oosthuizen (2005), even though his study was not done amongst ministers. Nel (2002) only indicated a negative correlation between social support and work-spouse interference.

From the results, the variables congregational support and job accomplishment also had positive significant relationships with the dimension of work-home interference, as well as with work-religion/spirituality interference. This suggests that, in cases where ministers experience support from their congregation and feel that they have accomplished their aims within their job, the interference with their home and spiritual life are less. On the other hand, job significance was found positively related to the dimension of workreligion/spirituality interference. This means that the more significance ministers attach to their job, the less interference there is in their sphere of spirituality. This could be because ministers experience their work as a calling (Smit 2004).

Upon investigation of the significant predictors for worknonwork interference for ministers, empirical results of the present study were in accordance with previous studies done in South Africa. These studies indicated that the imbalance of increasing job demands and the lack of job resources lead to work-nonwork interference (Koekemoer et al. 2010; Nel 2002; Oosthuizen et al. 2011).

Regarding the dimension of work-parent interference, the following variables were found as significant predictors in the present study: cognitive demands, pace and amount of work, financial support and turning to religion. If ministers have too much on their mind it would interfere with their parenting roles. This indicated that the cognitive strain and the amount of work which needs to be completed interfered with the ministers' ability to fulfil their parenting responsibilities. Oosthuizen et al. (2011) found in contradiction to the results that cognitive demands did not significantly predict the dimension of work-parent interference. On the other hand, if ministers received no financial support from the congregation, the result could be that they are unable to buy sufficient goods for their children; thus there is an interference with their expectation as parents. However, the results indicated that ministers use the strategy of turning to religion as a means to cope with the work-parent demands, and this might indicate that ministers also fulfil their roles as parents as part of their spiritual commitment. Thus ministers might make use of their turning to religion as a coping strategy when fulfilling their role as parents, and hence experience less interference from the work environment in their parenting roles.

With respect to the dimension work-home interference, the following variables were significant predictors: pace and amount of work and financial support. The results indicated that the amount of work and financial support were related to the interference from the work environment which ministers experienced at home. Oosthuizen et al. (2011) confirmed the relationship between work-home interference and work pressure, but found contradicting results for the variable financial support. 
With regard to the dimension of work-religion/spirituality interference, significant predictors were found to be: pace and amount of work, job significance and turning to religion. It would seem that the amount of work ministers have to complete interfered with the time they allocated for religion/ spiritual activity. Although ministers' occupation is of a religious nature, they neglect to spent time occupying their religion/spiritual role. Oosthuizen et al. (2011) confirmed that work pressure significantly predict work-religion/ spirituality interference. From the results it is also evident that there is a correlation between turning to religion as a coping mechanism, and work-religion/spirituality interference. This is in line with Koenig et al. (2001), who found that turning to religion as a coping strategy can be used to decrease the negative effect of stress and mental health.

\section{Practical application}

In the results of the present study, the pace and amount of work ministers seem to experience are definitely significant predictors for all three dimensions of work-nonwork interference. In respect of pace and amount of work it might help to set a clear indication of what the expectations and requirements (e.g. job descriptions) are for ministers. The congregation should be made aware of these demands, and it is advisable that they appoint individuals to assist ministers with daily administration and organisational tasks. Such actions may help to lower the demands in the ministers' work environment, which then may decrease their experience of work-nonwork interference.

In terms of the resources measured in this study, financial support and job significance apparently are the most significant predictors for work-nonwork interference. Research has indicated that the lack of financial support is an additional stressor for ministers (Buys 2008; Du Plessis 2009; Grobbelaar 2007; Jansen van Vuuren 2005). However, it is not a simple matter of increasing the ministers' salary. Alternative ways should be explored on how ministers could stretch their current income through effective budgeting and planning of expenditures. Currently the most common and efficient strategy congregations in the Dutch Reformed Church use to supplement ministers' salary, is by allowing tent-maker ministry. In addition to their occupation as minister of a church, ministers may render other professional services (e.g. as therapist, spiritual life-coach or language practitioner) to augment their income. This may also help to increase ministers' levels of job significance, where they feel they are needed.

In terms of coping strategies, the results indicated that the coping strategy of turning to religion has a significant decreasing effect on work-parent and work-religion/ spirituality interference. According to Koenig et al. (2001), there is growing scientific evidence that individuals who seek religion in their lives through regular religious practices, whether in congregation or private, are healthier and enjoy a longer life expectancy than those adults who have less religious participation. It is therefore important that ministers be a part of 'cell-groups' and Bible study groups to grow in their own faith. Meisenhelder and Marcum (2004) found that for ministers the most common coping strategy used were turning to religion. Time should be set aside for ministers to focus on their own personal spiritual growth and well-being. This could be achieved by having sufficient 'quiet time' alone to converse with their God in prayer for their own spiritual development.

\section{Limitations of the study}

Research of this nature will also have certain limitations. The first limitation relates to the composition of the sample population and the small sample size. The majority of respondents were from the Dutch Reformed Church in South Africa. Therefore generalisation of the results becomes problematic. Also using the three sister churches as part of the survey design might be a limitation, since only a white Afrikaner population is implicated. Also with such a small sample size it was not possible to employ advanced methods of statistical analyses, such as structural equation model (SEM) in the AMOS-statistical programme. The second limitation deals with the use of self-report questionnaires and the possibility of 'common-method-variance' or 'nuisance'. Chang, Van Witteloostuijn, and Eden (2010) explained this condition as a false internal consistency, which indicates an apparent correlation amongst variables that were developed by their common source (questionnaire). Finally, the use of a cross-sectional research design is another limitation, since no causal inferences can be drawn with cross-sectional data samples. Thus the relationships can merely be interpreted and not examined in depth. In order to validate hypothesised causal relationships, it is necessary to employ longitudinal designs.

\section{Recommendations}

Ministers should be made more aware of the different demands and the possible experience of work-nonwork interference (i.e. all three dimensions thereof). From the research it is evident that the most significant influence on ministers' work-nonwork interference comes from the pace and amount of work that ministers have to attend to. Even at a tertiary level this needs to be addressed. The institutional and regulatory functions of the Church need to be aware of this factor.

At this level ministers' training can include in the curriculum ways to deal with the demands indicated in this study. In the Dutch Reformed Church, another incentive to utilise is the system of so-called 'VBO-punte' [FVT or Further Vocational Training scores]. This is a system according to which incumbent ministers are awarded marks for attending a series of FVT courses per annum. Such refresher courses can be compiled to include work-nonwork interference and coping strategies. Short courses covering this subject can also be implemented as a joint initiative between higher education institutions and various theological training institutes. A possibility that can be explored is collaboration between 
different universities with similar academic departments as the School for Human Resource Sciences (North-West University) and various centres of ministerial development of the Dutch Reformed Church. Such centres can include Exelsus, the Centre for Ministerial Development espoused by the University of Pretoria; Communitas (University of Stellenbosch); and SHEPHERD (University of Free State). Strategic short courses can be developed to familiarise ministers of religion with the work-nonwork instruments, and empower them with scientific knowledge to apply the best coping strategies for their ministry.

For future research studies, more qualitative and longitudinal studies may provide a clearer in-depth picture of the work environments of ministers and their experience of such an environment. It is also recommended that the focus should not only be on the work-nonwork interference, but also on the interference of the nonwork-work environment on the work, as was done in the study of Koekemoer (2010) and Koekemoer et al. (2010). The distinct possibility exists that issues at home, such as marital tension, parental problems or negative neighbour relations or perceptions, can have a significant impact on ministers' fulfilment of their occupation as spiritual leaders.

Future study on this topic could also include females within the three Reformed sister churches. Thereby more balanced results can be obtained and gender equality can be maintained in the study focus. In this regard De Klerk and Mostert (2010) indicate that males experience significantly higher levels of negative work-home interference than women. Future studies may establish that female ministers are better able to balance the demands of their work with their home environment. Here the significance of the social networks as supporting system or coping strategy can be investigated (e.g. as self-employment opportunity or marketing tool of home-industry).

\section{Conclusion}

In a sense this research divulges facts that already are worryingly familiar to ministers of religion. Ministers are continually aware of the incongruence of increasing and taxing job demands and limited and decreasing job resources. As a result, ministers have tried and tested various coping strategies over time. However, due to a lack of systematic knowledge the efforts for the most had been haphazard and employed on an ad hoc basis.

The present study has a twofold impact. On the one hand it makes ministers aware of their job demands and the corresponding lack of resources. The study indicates that variables such as pace and amount of work, cognitive demands, as and the lack of financial support and job significance, all add to the pressure that ministers and their family's experience. Some ministers may not be aware of the negative effects that their occupation have on themselves as well as their family. The study informs ministers through empirical research findings of the interference their work role exerts on other roles in their personal lives (parental, home and religious).

Through this study ministers are made aware of these interferences, and are empowered by scientific knowledge of the most proficient coping strategies to balance their work and nonwork environment. Therefore ministers on a personal basis, and the church on an institutional basis, can have a more concerted and systematic approach to deal with this pressing problem that is impairing the ministry of religion.

\section{Acknowledgements}

The authors wish to acknowledge the valuable input and technical language editing provided by Claude Vosloo from 'homeofcreativity'.

\section{Competing interests}

The authors declare that they have no financial or personal relationship(s) that may have inappropriately influenced them in writing this article.

\section{Authors' contributions}

A.v.d.W. (North-West University) conducted this study as part of her master's dissertation whilst enrolled at the North-West University. E.K. (North-West University) acted as study leader, conducted the statistical analysis, and gave insight into the write-up of the manuscript.

\section{References}

Allen, T.D., Herst, D.E., Bruck, C.S. \& Sutton, M., 2000, 'Consequences associated with work-to-family conflict: A review and agenda for future research', Journal of Occupational Health Psychology 5, 278-308. http://dx.doi.org/10.1037/10768998.5.2.278

Bakker, A.B. \& Demerouti, E., 2006, 'The job demands-resources model: State of the art', Journal of Managerial Psychology 22, 309-328. http://dx.doi. org/10.1108/02683940710733115

Bakker, A.B., Demerouti, E. \& Verbeke, W., 2004, 'Using the Job Demands-Resources model to predict burnout and performance', Human Resource Management 43, 83-104. http://dx.doi.org/10.1002/hrm.20004

Bakker, A.B., Ten Brummelhuis, L.L., Prins, J.T. \& Van der Heijden, F.M.M.A., 2011 'Applying the Job-Demands Resources model to the work-home interface: A study among medical residents and their partners', Journal of Vocational Behavior 79 170-180. http://dx.doi.org/10.1016/j.jvb.2010.12.004

Baron, R.M. \& Kenny, D.A., 1986, 'The moderator-mediator variable distinction in social psychological research: Conceptual, strategic, and statistical considerations', Journal of Personality and Social Psychology 51(6), 1173-1182. http://dx.doi. org/10.1037/0022-3514.51.6.1173

Bartlett, G.E., 1957, 'The minister, pastor or promoter?', Pastoral Psychology 8(6), 12-16. http://dx.doi.org/10.1007/BF02063099

Bryman, A. \& Bell, E., 2007, Business research methods, 2nd edn., Oxford University Press, New York.

Bulger, C.A., Matthews, R.A. \& Hoffman, M.E., 2007, 'Work and personal life boundary management: Boundary strength, work/personal life balance, and the segmentation-integration continuum', Journal of Occupational Health Psychology 12(4), 365-375. http://dx.doi.org/10.1037/1076-8998.12.4.365

Buys, C., 2008, 'The well-being of ministers in South Africa', PhD thesis, North-West University.

Buys, C. \& Rothmann, S., 2009, 'Job demands and job resources in the ministry', South African Journal of Human Resource Management 7(1), 1-10.

Byron, K., 2005, 'A meta-analytic review of work-family conflict and its antecedents', Journal of Vocational Behavior 67, 169-198. http://dx.doi.org/10.1016/j. jvb.2004.08.009

Carver, C.S., Scheier, M.F. \& Weintraub, J.K., 1989, 'Assessing coping strategies: A theoretically based approach', Journal of Personality and Social Psychology 56, 267-283. http://dx.doi.org/10.1037/0022-3514.56.2.267 
Chang, S., Van Witteloostuijn, A. \& Eden, L., 2010, 'From the editors: Common method variance in international business research', Journal of International Business variance in internation
Studies $41,178-184$.

Clark, L.A. \& Watson, D., 1995, 'Constructing validity: Basic issues in objective scale development', Psychological Assessment 7, 309-319. http://dx.doi. org/10.1037/1040-3590.7.3.309

Cohen, J., 1988, Statistical power analysis for the behavioural sciences, 2nd edn., Academic Press, Orlando.

Darling, C.A., Hill, E.W. \& McWey, L.M., 2004, 'Understanding stress and quality of life for clergy and clergy spouses', Stress and Health 20(1), 261-277. http://dx.doi. org/10.1002/smi.1031

De Klerk, M. \& Mostert K., 2010, 'Work-home interference: Examining sociodemographic predictors in the South African context', South African Journal of Human Resource Management 8(1), 203-213.

Demerouti, E., Bakker, A.B. \& Bulters, A.J., 2004, 'The loss spiral of work pressure, work home interference and exhaustion: Reciprocal relations in a three-wave study', Journal of Vocational Behavior 64, 131-149. http://dx.doi.org/10.1016/ S0001-8791(03)00030-7

Demerouti, E., Bakker, A.B., Nachreiner, F. \& Schaufeli, W.B., 2001, 'The Job Demands Resources Model of burnout', Journal of Applied Psychology 86(3), 499-512. Resources Model of burnout', Journal of Applied
http://dx.doi.org/10.1037/0021-9010.86.3.499

Doolittle, B.R., 2010, 'The impact of behaviors upon burnout among parish-based clergy', Journal of Religion and Health 49, 88-95. http://dx.doi.org/10.1007/ s10943-008-9217-7

Doumas, D.M., Margolin, G. \& John, R.S., 2008, 'Spillover patterns in single-earner couples: Work, self-care, and the marital relationship', Journal of Family Economic Issues 29, 55-73. http://dx.doi.org/10.1007/s10834-007-9091-6

Du Plessis, J.C., 2009, 'Heling van die familie: 'n Kritiese ondersoek na pastorale dimensies van die liturgie', Meestersverhandeling, Universiteit Stellenbosh.

Field, A., 2013, Discovering statistics using IBM SPSS Statistics, 4th edn., SAGE, London.

Francis, L.J., Craig, C.L., Whinney, M., Tilley, D. \& Slater, P., 2000, 'Psychological typology of Anglican religious leaders in England: Diversity, strengths, and weaknesses in ministry', Journal of Psychology and Theology 11, 266-284.

Geurts, S.A.E. \& Demerouti, E., 2003, 'Work/non-work interface: A review of theories and findings', in M. Schabracq, J. Winnubst \& C.L. Cooper (eds.), Handbook of work and health psychology, pp. 279-312, Wiley, Chichester.

Gibbs, E., 2000, Church next: Quantum changes in how we do ministry, InterVarsity, Downers Grove.

Glaser, K., Evandrou, M. \& Tomassini, C., 2006, 'Multiple role occupancy and socia participation among midlife wives and husbands in the United Kingdom International Journal of Aging and Development 63, 27-47. http://dx.doi. org/10.2190/7LGV-01W9-KQBL-4121

Greenhaus, J.H. \& Beutell, N.J., 1985, 'Sources of conflict between work and family roles', Academay of Management Review 10, 76-88. http://dx.doi. org/10.2307/258214

Grobbelaar, K.G., 2007, 'Hulpverlening tot streshantering by predikante van die Gereformeerde Kerke in Suid-Afrika (GKSA): 'n Pastorale studie, PhD-tesis, Noordwes-Universiteit.

Grosch, W.N. \& Olsen, D.C., 2000, 'Clergy burnout: An integrative approach', Psychotherapy in Practice 56(5), 619-632.

Haden, S.C., Scarpa, A., Jones, T.R. \& Ollendick, T.H., 2007, 'Posttraumatic stress disorder symptoms and injury: The moderating role of perceived social support and coping for young adults', Personality and Individual Differences 42, 11871198. http://dx.doi.org/10.1016/j.paid.2006.09.030

Hall, G.B., Dollard, F.D., Turkey, M.R., Winefield, A.H. \& Thompson, B.M., 2010, 'Job demands, work-family conflict, and emotional exhaustion in police officers: A longitudinal test of competing theories', Journal of Occupational and Organizational Psychology 83, 237-250. http://dx.doi.org/10.1348/096317908X401723

Han, J. \& Lee, C., 2004, 'Ministry demand and stress among Korean American pastors: A brief report', Pastoral Psychology 52(6), 473-478. http://dx.doi.org/10.1023/ B:PASP.0000031525.27365.0c

Hang-yue, N., Foley, S. \& Loi, R., 2005, 'Work role stressors and turnover intentions: A study of professional religious leaders in Hong Kong', International, Journal of Human Resource Management 16(2), 133-2146.

Hill, E.W., Darling, C.A. \& Raimondi, N.M., 2003, 'Understanding boundary-related stress in religious leaders families', Marriage \& Family Review 35(2), 147-166. $\mathrm{http}: / / \mathrm{dx}$.doi.org/10.1300/J002v35n01_09

Innstrand, S.T., Langballe, E.M. \& Falkum, E., 2010, 'The longitudinal effects of individual vulnerability, organisational factors, and work-home interaction on burnout among male church ministers in Norway', Mental Health, Religion \& Culture 14(3), 241-257. http://dx.doi.org/10.1080/13674670903470621

Jansen van Vuuren, Y., 2005, 'Work wellness of Pentecostal pastors in the North-West Province', master's dissertation, North-West University.

Kalliath, P. \& Kalliath, T., 2013, 'Work-family conflict and its impact on job satisfaction of social workers', British Journal of Social Work, 1-19.

Koekemoer, E., 2010, Work-nonwork interference in the South African context', doctoral thesis, North-West University.

Koekemoer, E. \& Mostert, K., 2006, 'Job characteristics, burnout and negative workhome interference in a nursing environment', South African Journal of Industria Psychology 3(3), 87-97.

Koekemoer, E. \& Mostert, K., 2010, 'Work-nonwork interference: Preliminary results on the psychometric properties of a new instrument', South African Journal of Industrial Psychology 36(1), 1-13. http://dx.doi.org/10.4102/sajip.v36i1.908
Koekemoer, E., Mostert, K. \& Rothmann, S., 2010, 'Interference between work and nonwork roles: The development of a new South African instrument', South African Journal of Industrial Psychology 36(1), 1-14. http://dx.doi.org/10.4102/ sajic.v36i1.907

Koenig, H.G., McCullough, M.E. \& Larson D.B., 2001, Handbook of religion and health, Oxford University Press, Oxford. http://dx.doi.org/10.1093/acprof:o so/9780195118667.001.0001

Kriel, J.S., Wilders, C.J., Strydom, G.L. \& Breytenbach, H.S., 2005, 'Die interaksie van fisieke aktiwiteit met die verband tussen lewensgeluk en diensjare, gemeentegrootte, medeleraarskappe en gemeentetipe by NG predikante in SuidAfrika', Dutch Reformed Theological Journal 46(1/2), 165-179.

Lee, J.A. \& Phillips, S.J., 2006, 'Work and family: Can you have it all?', The PsychologistManager Journal 9, 41-57. http://dx.doi.org/10.1207/s15503461tpmj0901_5

Mauno, S., Kinnunen, S. \& Ruokolainen, U., 2006, 'Exploring work- and organization-based resources as moderators between work-family conflict, well-being, and job attitudes', Work \& Stress 20(3), 210-233. http://dx.doi. org/10.1080/02678370600999969

Meisenhelder J.B., \& Marcum J.P., 2004, 'Responses of religious leaders to 9/11: Posttraumatic stress, coping, and religious outcomes', Journal for the Scientific Study of Religion 43(4), 547-554. http://dx.doi.org/10.1111/j.14685906.2004.00255.x

Mesmer-Magnus, J.R. \& Viswesvarum, C. 2005, Convergence between measures of work-to-family and family-to-work conflict: A meta-analytic examination, Journal of Vocational Behaviour 67, 215-232. http://dx.doi.org/10.1016/j. jvb.2004.05.004

Mostert, K. \& Oosthuizen, B., 2006, 'Job characteristics and coping strategies associated with negative and positive work-home interference in a nursin environment', South African Journal of Economic Management Sciences 9(4), 429-443.

Mostert, K., Peeters, M. \& Rost, I., 2010, 'Work-home interference and the relationship with job characteristics and well-being: A South African study among employees in the construction industry', Stress and Health 27, 238-251. http://dx.doi. org/10.1002/smi.1374

Nel, J., 2011, 'Home characteristics, nonwork-work interference and well-being of dual earner parents', master's dissertation, North-West University. http://dx.doi. org/10.4102/ve.v23i1.1215

Nel, M., 2002, 'Predikanteopleiding: Roeping, keuring en legitimering', Verbum et Ecclesia 23, 151-167. http://dx.doi.org/10.4102/ve.v23i1.1215

Nunnally, J.C. \& Bernstein, I.H., 1994, Psychometric theory, 3rd edn., McGraw-Hill, New York.

Oosthuizen, B., 2005, 'Job characteristics, coping and work-home interaction in a nursing environment', master's dissertation, North-West University.

Oosthuizen, J., Koekemoer, E. \& Mostert, K., 2011, 'Job characteristics, worknonwork interference and the role of recovery strategies amongst employees in a tertiary institution', South African Journal of Human Resource Management 9(1), $1-15$.

Pargament, K.I., Tarakeshwar, N., Ellison, C.G. \& Wulff, K.M., 2002, 'Religious coping among the religious: The relationship between religious coping and the well-being in a national sample of Presbyterian clergy, elders and members', Journal for the Scientific Study of Religion 40(3), 497-513. http://dx.doi.org/10.1111/00218294.00073

Peeters, M., Montgomery, A.J., Bakker, A.B. \& Schaufeli, W.B., 2005, 'Balancing work and home: How job and home demands are related to burnout', International Journal of Stress Management 12, 43-61. http://dx.doi.org/10.1037/1072 5245.12.1.43

Pienaar, J. \& Rothmann, S., 2003, 'Coping strategies in the South African Police Service', South African Journal of Industrial Psychology 29(4), 81-90.

Premeaux, S.F., Adkins, C.L., \& Mossholder, K.W., 2007, 'Balancing work and family: A field study of multi-dimensional, multi-role work-family conflict', Journal of Organizational Behaviour 28, 705-727. http://dx.doi.org/10.1002/ job.439

Rantanen M., Mauno, S., Kinnunen, U. \& Rantanen, J., 2011, 'Do individual coping strategies help or harm in the work-family conflict situation? Examining coping as a moderator between work-family conflict and well-being', Internationa Journal of Stress Management 18(1), 24-48. http://dx.doi.org/10.1037/ a0022007

Salkind, N.J., 2009, Exploring research, Pearson Prentice, Englewood Cliffs. http:// dx.doi.org/10.1037/a0022007

Schaufeli, W.B. \& Bakker, A.B., 2004, 'Job demands, job resources, and their relationship with burnout and engagement: A multi-sample study', Journal of Organizational Behavior 25, 293-315. http://dx.doi.org/10.1002/job.248

Smit, J., 2004, 'Die predikant: 'n Werknemer van die kerkraad?', Nederduitse Gereformeerde Teologiese Tydskrif 45(1/2), 88-98.

Struwig, F.W. \& Stead, G.B., 2001, Planning, designing and reporting research, Pearson Education, Cape Town.

Swart, T., 2002, 'Aspekte met betrekking tot uitbranding by predikante van die NG Kerk', Meestersverhandeling, Randse Afrikaanse Universiteit.

Van Emmerik, I.J.H., Bakker, A.B. \& Euwema, M.C., 2009, 'Explaining employees' evaluations of organizational change with the job-demands resources model', Career Development International 14(6), 594-613. http://dx.doi.org/10.1108/ 13620430910997312

Yildirim, D. \& Aycan, Z., 2008, 'Nurses' work demands and work-family conflict: A questionnaire survey', International Journal of Nursing Studies 45, 1336-1378. http://dx.doi.org/10.1016/j.ijnurstu.2007.10.010 